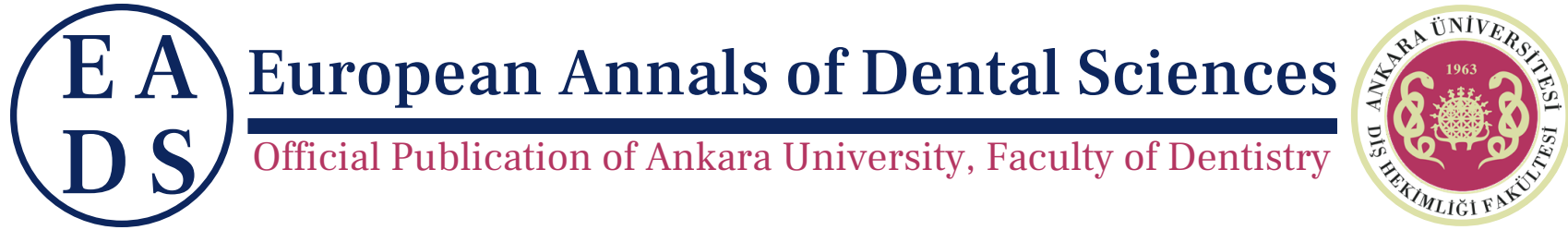

EADS, 2021, 48 (1), 33-39

\title{
Biocompatibility Evaluation of Resin-Based Restorative Materials: A Review
}

\author{
Ceren Çimen $\odot 1$,* and Nurhan Özalp ${ }^{2}$ \\ ${ }^{1}$ DDS, Department of Pediatric Dentistry, Faculty of Dentistry, Ankara University, Ankara, Turkey and ${ }^{2}$ DDs, \\ $\mathrm{PhD}$, Department of Pediatric Dentistry, Faculty of Dentistry, Ankara University, Ankara, Turkey \\ *Corresponding Author; cerencimen45@gmail.com
}

\begin{abstract}
Biocompatibility is described as an appropriate biological response of a biomaterial in a living organism. It is known that biomaterials are not inert and the materials should be tested before they are allowed to be used in clinical practice. Various test methods have been developed and protocols have been determined for this purpose. Resin-based restorative materials are extensively used in dentistry due to the increased aesthetic demands of patients and the ease of use in clinical practice. As the restorative materials function in the mouth for long years, concerns about the biocompatibility of resin-based restorative materials become more important. Regarding the importance of this issue, the purpose of this review was to evaluate the local and systemic potential toxicity of resin-based restorative materials, toxicity test methods, and the mechanism of the cytotoxicity in living tissues.
\end{abstract}

Key words: Biocompatibility; Cytotoxicity; Dental restorative material; Photopolymerization; Resin monomer

\section{Definition of biocompatibility and test meth- ods}

Biocompatibility is described as an ability of a biomaterial to perform its desired property without any adverse reactions in the beneficiary of the material. ${ }^{1}$ When the material is placed in the living organism, interactions occur with the complex biologic system of the host which results in a biological response. Biocompatibility is a dynamic process and the biological response may change over time depending on the interactions between the host, material and the function of the material. ${ }^{2,3}$ Dental materials are considered as biomaterials and they are expected to be nontoxic in living tissues. The materials are strictly tested by regulatory agencies before they are allowed to be used in clinical practise. The test methodologies are specified as in vitro, animal and usage tests. $^{2}$

1- In vitro tests: In vitro tests are conducted outside of a living organism in laboratory conditions. ISO 10993 series for medical devices and 7045 series, which are specialized for devices used in dentistry have been developed for standardization of in vitro tests. These series include the biological evaluation of materials, the classification and description of test methods for biocompatibility evaluation in different aspects. The disadvantage of in vitro tests is their disputable relevance to the final usage of the material in a biological system. ${ }^{4,5}$ In vitro cytotoxicity assays measure viability, plating efficiency or metabolic activity of the cells. Several tests such as lactate dehydrogenase (LDH) assay, 2-(4-iodophenyl)3-(4-nitrophenyl)-5-(2,4-disulfophenyl)-2H-tetrazolium (WST-1) assay, 3-(4,5-dimethyl-2-thiazolyl)-2,5-diphenyl$2 \mathrm{H}$ tetrazolium bromide (MTT) assay, neutral red uptake, trypsin blue test are used to assess the biocompatibility of dental materials. ${ }^{4,6}$ However, these tests are in the format of end-point tests that continuous monitoring of the cell response is not possible. Recently, real time assay systems are devised for dynamic measurement of cell growth and viability. ${ }^{6}$ These systems allow the measurement through many time points and create line graph that reflect the biological status of the cells. It is reported that real time cell assay systems help to obtain more realistic results compared to single end-point values of conventional cytotoxicity tests. ${ }^{7}$

2- Animal tests: If the results obtained through in vitro tests meet the material requirements, more extensive research is performed on experimental animals. Animal tests enable the observation of more complex reactions between the recipient and the tested material. However, it is difficult to control variables, time consuming, expensive and ethically 
controversial. $3,5,8$

3- Usage tests: In the final stage, the material determined to be biocompatible as a result of laboratory and animal experiments are used on volunteers. The usage tests are accepted as gold standard and give decisive result for investigation of the biocompatibility of the material. ${ }^{4,5}$ Parameters such as pulpal and periodontal reactions, gingiva and oral mucosa irritations are evaluated in usage tests for dental materials. ${ }^{9}$

\section{Biocompatibility evaluation of resin-based restorative materials}

Resin-based restorative materials consist of an organic polymerizable matrix, filler materials, molecules initiating the polymerization reaction and silane coupling agents. ${ }^{10}$ Mainly used components of the organic matrix are methacylate resin monomers such as bisphenol-A-glycidyldimethacrylate (Bis-GMA), hydroxyethyl methacrylate (HEMA) triethyleneglycol dimethacrylate (TEGDMA), urethane dimethacrylate (UDMA). ${ }^{11}$

The photopolymerization of resin-based restorative materials is initiated by reaction of free radicals with methacrylate monomers and results in the generation of a highly cross-linked polymer structure. ${ }^{12}$ As the photopolymerization proceeds, the viscosity of the cross-linked polymer network becomes so high which restricts the reaction of monomer molecules. Thus, the photopolymerization can not be completed even in optimal conditions. The ratio of double bonds that join the polymer network to the initial amount, expressed in $\%$ is defined as the degree of conversion. ${ }^{13}$ The conversion of monomer to polymer in resin-based restorative materials varies between $43 \%$ to $75 \%$ and this ratio decreases to $35 \%$ in the presence of an oxygen inhibition layer. ${ }^{14}$ Consistent with this result, studies have reported that acute release of monomers occurs in the first 24 hours. ${ }^{15,16}$ Unreacted monomers eluted from resin-based restorative materials have been considered as a reason of hypersensitivity, allergic reactions, local and systemic toxic effects. ${ }^{17}$ Therefore, it is critical to maximize the degree of conversion in order to obtain a more biocompatible restorative material. ${ }^{18}$ It has been reported that the degree of conversion further increased to nearly $95 \%$ when the oxygen inhibition layer was removed by finishing and polishing techniques. ${ }^{19}$

\section{Long-term monomer release of resin-based restora- tive materials}

Dental restorations are in interaction with the oral environment dynamically. As resin-based restorative materials are expected to function for long years, they may degrade and components of the materials release into the oral environment in time. The reasons for degradation could be chewing forces, microorganisms, temperature changes, enzymes or saliva. ${ }^{20}$ Mastication: While functioning, resin-based restorative materials are exposed to mechanical stress constantly. This situation results in wear on restoration surface and the release of components from the material. ${ }^{20}$ Saliva: The main ingredient of the saliva is water. Since dental resins are polar molecules, water molecules easily penetrate the polymer network and ease the release of unreacted monomers. ${ }^{21}$ In addition saliva, $\mathrm{pH}$ can vary from alkaline to acid and may cause chemical deterioration to dental restorations. ${ }^{20}$ Microorganisms: Lactic acid produced by bacterias promotes the hydrolisis of the restoration. In addition, oral biofilm formation may also cause degradation, thus revealing different components from the restora- tion. ${ }^{20,22}$ Enzymes: Some form of enzymes that are present in saliva and dentinal fluid are responsible for the breakdown of the linkages. The endopeptidases comprise matrix metalloproteinases and cysteine cathepsins are capable of hydrolytic degradation of hybrid layer. ${ }^{23}$ In vitro studies confirmed the long-term elution of monomers for 1,3 , and 12 months. ${ }^{16,24,25}$ It was also claimed that monomer elution is expected to be increased by the degradation and wear in the oral environment. Biocompatibility studies are mainly focused on the release of unreacted monomers in short-term period; whereas biodegradation of restorative materials and metabolic by-products also play a crucial role on potential toxicity in living tissues. ${ }^{26}$ The long-term effects of unreacted monomers on biocompatibility are still unclear. Long-term chronic exposure and systemic adverse effects must also be considered when assessing the potential toxicity of the eluted compounds. ${ }^{24}$

\section{Release of formaldehyde}

Small amounts of formaldehyde may be released from dental polymers as a result of oxidation of unreacted methacrylate groups or degradation of the oxygen inhibition surface layer ${ }^{27}$. Oysaed et al. ${ }^{27}$ reported that using mylar strips during polymerization or finishing the restoration surface using sandpapers caused a significant decrease in the release of formaldehyde. The amount of formaldehyde was still detectable even after 115 days although the concentrations were below toxic levels. Formaldehyde could also be released as a metabolic byproduct of TEGDMA. ${ }^{26}$ But, it has been shown that TEGDMAmetabolites in organs have not reached toxic levels in guinea pigs. ${ }^{28}$ Another in vitro study confirmed that the levels of formaldehyde do not cause toxic effects in human pulmonary cells. ${ }^{26}$

\section{Release of Bisphenol-A}

Bisphenol A (BPA) is a synthetic chemical generally found in polycarbonate plastics and epoxy resins. Free BPA is absorbed through the skin, oral mucosa, respiratory epithelium or gastrointestinal system. Various epidemiological studies have reported an association between BPA exposure and obesity, asthma and neuro-behavioural disorders in children. ${ }^{29-31}$ The tolerable daily intake is advised by governmental regulatory agencies. European Food Safety Authority (EFSA) derived a reference dose of $0,004 \mathrm{mg} \mathrm{BPA} / \mathrm{kg}^{32}$, The United States Environmental Protection Agency (USEPA) determined the tolerable daily intake as $0,05 \mathrm{mg} \mathrm{BPA} / \mathrm{kg}$. $33 \mathrm{BPA}$ is not included as a substance in dental materials, whereas BPA derivatives such as Bis-DMA and Bis-GMA are used in their structures. ${ }^{34}$ However, it has been shown that Bis-DMA has been hydrolyzed to BPA through salivary esterases. The chemical structure of BisGMA prevents hydrolysis at ester linkages and it is not affected by enzymatic hydrolysis. ${ }^{35,36}$ Salivary BPA concentration decreased over time with different concentrations across in vivo studies; $34,37-39$ the highest exposure $(385 \mathrm{ng} / \mathrm{mL})$ was measured 10 minutes after placement and lowest exposure $(0,25$ $\mathrm{ng} / \mathrm{mL}$ ) measured 1 week after placement. ${ }^{37}$ It was observed that BPA levels in saliva returned to pretreatment levels in 8 hours ${ }^{40}$ to 1 month ${ }^{34}$ after placement. BPA concentration in urine is another indicator to measure systemic exposure. Urinary BPA level was increased in the range of $43 \% 40$ and $354 \%{ }^{41} 24$ hours after the placement in vivo studies. However, the concentrations were similar to pretreatment levels 1 month after treatment. ${ }^{42-44}$ Maserejian et al. ${ }^{45}$ reported there was no association between placement of resin-based restorative materials and neuropsychological, behavioral or physical development in pediatric patients over 5 years. In conclu- 
sion, $40,46,47$

- Photopolymerizable restorative materials should be used as an alternative to self-curing restorative materials and BisGMA should be preferred instead of Bis-DMA in resin composition of materials.

- Restorations should be placed with a rubber dam to reduce elution in saliva and more than four treatments per appointment should not be performed.

- Finishing and polishing procedures should be applied to remove oxygen inhibition layer.

- Gargling for 30 seconds after placement of restoration is suggested for dilution of BPA concentration.

\section{Estrogenic effects}

BPA mimics estrogen-like activity by binding to the estrogen receptors at subtoxic concentrations. ${ }^{48}$ It has been demonstrated that BPA and Bis-DMA significantly stimulated estrogenic activity while Bis-GMA did not have such effect. 36,49 The minimum concentration at which Bisphenol-A caused estrogenic activity was calculated as $0.1 \mu \mathrm{mol} / \mathrm{L}$ and above 1 $\mu \mathrm{mol} / \mathrm{L}$ for hydroxy-4-methoxy-benzophenone (HMBP), 2,2dimethoxy-2-phenylacetophenone (DMPA) and 2,6-di-tetrabutyl-p-cresol (BHT). ${ }^{49}$ Some researchers claimed that leachable concentrations from resin-based restorative materials were below the reported dose required for estrogenicity, 50,51 while other in vitro studies found evidences for estrogenic activity. ${ }^{49,52}$

\section{Systemic toxicity}

The systemic intake of components released from resin-based composites can be through oral mucosa epithelium, via dentinal tubules to pulp, absorption from respiratory system or gastrointestinal tract. ${ }^{53-55}$ Potential systemic or reproductive toxic effects of resin monomers were investigated in various animal studies. The monomers did not reach to a dose that would cause systemic or reproductive toxic effects and were mostly excreted via different pathways. ${ }^{28,56,57}$ In preclinical studies, acute oral toxicity is determined by the Lethal Dose 50 (LD50), which is the calculated dose that kills $50 \%$ of the experimental population. ${ }^{2}$ According to the European Union, the Regulation on Classification, Labelling and Packaging, the chemicals with LD50 of $<2000 \mathrm{mg} / \mathrm{kg}$ bw are necessitated to be labelled for acute oral toxicity. ${ }^{58}$ None of LD50 values of dental monomer and comonomers were found to be above this value in animal studies. Therefore an acute oral toxicity can not be expected for resin-based restorative materials. ${ }^{2}$

\section{Local toxicity}

Substances leached from resin-based restorative materials may generate toxic effects in adjacent tissues such as gingiva, oral mucosa or alveolar bone. ${ }^{2}$ Local toxicity is measured with a value of Toxic Concentration50 (TC50), the concentration that causes a reduction in cell metabolism or death by $50 \%)^{2,3}$ Many in vitro studies have been conducted to determine cytotoxicity of resin-based restorative materials and contradictory results have been obtained. ${ }^{19,59,60}$ The results show differences depending on the resin composition of the material, cell type or test methods. Human cell lines are found to be more sensitive to long-term incubation with composites than mammalian cell lines. ${ }^{61}$ Human gingival cells and $3 \mathrm{~T} 3$ fibroblast cells are reported to be less sensitive than human pulp cells in another study ${ }^{62}$. Nascimento at al. ${ }^{60}$ revealed different re- sults between the neutral red and MTT tests. Rajic et al. ${ }^{63}$ found that cured forms of composites did not show any toxic effect, whereas uncured forms exhibited a certain level of toxicity. Completely curing is not always possible due to the existence of saliva or anatomical problems in clinical conditions. Therefore, biocompatibility should be tested in vitro and in vivo to clarify actual effects of the restorative materials. ${ }^{19}$

\section{Cytotoxic effects on cell metabolism}

Reactive oxygen species (ROS) are generated either by metabolic reactions of the cells or result from exposure to radiation, UV light or other environmental factors. ROS function in signaling pathways in low-moderate concentrations, but overproduction of ROS is linked to various diseases such as cancer, early aging, neurodegenerative disorders. The human body has a complex defense system including a variety of antioxidants that balances the cell-damaging effects of ROS. Glutathione is a thiol antioxidant that is capable of preventing damage to important cellular departments caused by ROS. ${ }^{64,65}$ Studies have shown that concentrations of $0,1 \mathrm{mM}$ Bis-GMA, ${ }^{66} 0.33 \mathrm{mM}$ TEGDMA, 1.6mM HEMA and $0.1 \mathrm{mM}$ UDMA deplete the intracellular glutathione levels and promote cell damage in a concentration-dependent manner in human gingival fibroblasts. ${ }^{67}$ Furthermore, glutathione depletion caused by TEGDMA, HEMA and Bis-GMA is associated with subsequent increase of ROS, which may have a contribution to the toxicity of these monomers. ${ }^{68-70}$ Antioxidants such as $\mathrm{N}$-acetylcysteine, ascorbate, Trolox may have the potential to inhibit the detrimental effects of monomers. ${ }^{71,72}$ HEMA and TEGDMA have been considered as reason of arrest at phases of the cell cycle which leads to growth retardation, cytotoxicity or apoptosis. ${ }^{73}$ Apoptosis is a programmed physiological process of cell death, meanwhile necrosis is usually promoted by tissue inflammation associated with clinical symptoms. ${ }^{74} \mathrm{Re}-$ ichl et al. ${ }^{75}$ reported that TEGDMA induces apoptosis; HEMA, Bis-GMA and UDMA mainly induced necrotic cell death. Another in vivo study presented that the number of apoptotic epithelium cells was decreased in patients with amalgam restorations with an aging time of 1 week while that of composite was increased. ${ }^{76}$ The toxicity for the monomers was ranked as BisGMA > UDMA > TEGDMA> HEMA. It is claimed that the highest toxicity of Bis-GMA could be explained by the liposolubility of Bis-GMA since the phospholipid layer constitutes a major component of cell membrane. 77

\section{Genotoxicity studies}

The human genome is constantly being damaged by different chemical components and genome instability leads to the development of chronic degenerative diseases. Genetic damage is assessed in various methods such as detection of chromosomal or clastogenic changes, micronuclei formation, sister chromatid exchanges, base mutations. ${ }^{78}$ The studies investigating genotoxic potentials of dental polymers confirmed that resin monomers induced DNA damage on human peripheral blood lymphocytes, gingival fibroblasts, macrophages. ${ }^{79-81}$ Bis-GMA induced DNA strand breaks and micronucleated cells in a dose-related manner in murine macrophages in another study. ${ }^{82}$

Genotoxicity of composite and amalgam restorations were analyzed by using peripheral blood cells from individuals in some studies. Di Pietro et al. ${ }^{83}$ revealed that restorative materials exhibited genotoxic effects increased by time and number of the fillings. Whereas, other studies did not present any evidence regarding genotoxicity of composite resins. ${ }^{63,84,85}$ Further research about genotoxicity is required as neither of these 
in vivo studies evaluated the restorative materials directly on genetic material.

\section{Antimicrobial properties}

Components of resin-based restorative materials are thought to have a contribution to bacterial growth. Hansel et al. ${ }^{86}$ published that comonomers EGDMA and TEGDMA promote proliferation of cariogenic bacterias such as Streptococcus sobrinus and Lactobacillus acidophilus. Another study revealed that TEGDMA increased the proliferation of Streptococcus mutans and Streptococcus salivarius in $\mathrm{pH}$-dependent manner. ${ }^{87}$ This situation also contributes to the explanation of secondary caries developing under resin-containing restorations. Some researchers have denied the cytotoxic effects of resin monomers on pulp and blamed bacterial contamination. It has been believed that the space between restorative material/ adhesive and cavity walls creates an area for bacterial colonization and the acid production of the bacteria has an effect on the pulp. ${ }^{88}$ The gap has been reduced below $1 \mu \mathrm{m}$ in new generation adhesive systems. However, even this distance is sufficient for the colonization of bacteria such as Lactobacillus, whose diameter is smaller than 0.1 micrometer. ${ }^{10}$ Streptococcus mitis a bacterium that is the predominant species in soft tissue surfaces and saliva. It was reported that co-cultivation of Streptococcus mitis with human gingival fibroblasts caused a significant decrease in toxic effects of HEMA and the mortality of human gingival fibroblasts decreased after 48 and 72 hours. ${ }^{89}$

\section{Conclusion}

The release of free monomers from resin-based materials into the oral cavity occurs immediately after polymerization and in the long-term. An effective polymerization of the restorative material plays an important role in reducing residual monomer. The manufacturer's recommendations such as light source, light intensity, curing time should be followed during polymerization. Rubber dam should be used in order to prevent the monomers from joining the systemic circulation. After polymerization, the oxygen inhibition zone should be removed with finishing and polishing agents.

In vitro studies have shown that monomers released into the oral cavity have the potential to show cytotoxic effects. Results of in vitro and in vivo biocompatibility evalution of resinbased restorative materials vary across the studies. In vitro tests are often preferred because they are reproducible and easy to control variables. However, in vitro studies show more sensitivity to materials than in vivo studies as laboratory conditions can not completely mimic clinical conditions. Therefore, the most effective way to evaluate biocompatibility is the combined use of in vitro and in vivo tests.

Endodontics is a field of dentistry where relatively urgent applications are concentrated. For this reason, since the Covid19 outbreak started, endodontists in particular have difficulty in delaying treatment. However, the full implementation of the recommended treatment approaches and measures may make it possible to overcome this pandemic period with the least damage.

\section{Author Contributions}

C.Ç and N.Ö conceived the ideas; C.Ç collected and analysed the data; C.Ç and N.Ö led the writing.

\section{Conflict of Interest}

The authors of the current article certify that they have no affiliations with any organization or entity with any financial interest.

\section{Authors' ORCID(s)}

C.Ç. $\quad 0000-0002-0641-0831$

N.Ö. $0000-0003-4192-2960$

\section{References}

1. Perrotti V, Piattelli A, Quaranta A, Gómez-Moreno G, Iezzi G. 1. In: Shelton R, editor. Biocompatibility of dental biomaterials. Elsevier; 2017. p. 1-7.

2. Schmalz G, Arenholt-Bindslev D. Biocompatibility of dental materials. Vol. 1.. vol. 1. Berlin: Springer; 2009.

3. Wataha JC. Principles of biocompatibility for dental practitioners. J Prosthet Dent. 2001;86(2):203-209. doi:10.1067/mpr.2001.117056.

4. Freshney RI. Culture of animal cells: a manual of basic technique and specialized applications. John Wiley \& Sons; 2015.

5. Sakaguchi RL PJ ferracane J. Craig's restorative dental materials 14th ed. Philadelphia, PA: Elsevier/Mosby; 2018.

6. Urcan E, Haertel U, Styllou M, Hickel R, Scherthan H, Reichl FX. Real-time xCELLigence impedance analysis of the cytotoxicity of dental composite components on human gingival fibroblasts. Dent Mater. 2010;26(1):51-58. doi:10.1016/j.dental.2009.08.007.

7. Teng Z, Kuang X, Wang J, Zhang X. Real-time cell analysis-a new method for dynamic, quantitative measurement of infectious viruses and antiserum neutralizing activity. J Virol Methods. 2013;193(2):364-370. doi:10.1016/j.jviromet.2013.06.034.

8. Balkan A, Balkan M. Hayvan Çalismalarinda Etik, Laboratuar Standardizasyonu ve Hayvan Bakimi ile Ilgili Yasal Zorunluluklar. Turk Toraks Dergisi. 2013;14:6. doi:10.5152/ttd.2013.44.

9. Murray PE, García Godoy C, García Godoy F. How is the biocompatibilty of dental biomaterials evaluated? Med Oral Patol Oral Cir Bucal. 2007;12(3):E258-266.

10. Goldberg M. In vitro and in vivo studies on the toxicity of dental resin components: a review. Clin Oral Investig. 2008;12(1):1-8. doi:10.1007/s00784-007-0162-8.

11. Zorzin J, Maier E, Harre S, Fey T, Belli R, Lohbauer U, et al. Bulk-fill resin composites: polymerization properties and extended light curing. Dent Mater. 2015;31(3):293-301. doi:10.1016/j.dental.2014.12.010.

12. Pratap B, Gupta RK, Bhardwaj B, Nag M. Resin based restorative dental materials: characteristics and future perspectives. Jpn Dent Sci Rev. 2019;55(1):126-138. doi:10.1016/j.jdsr.2019.09.004.

13. Leprince JG, Palin WM, Hadis MA, Devaux J, Leloup G. Progress in dimethacrylate-based dental composite technology and curing efficiency. Dent Mater. 2013;29(2):139156. doi:10.1016/j.dental.2012.11.005.

14. Komurcuoglu E, Olmez S, Vural N. Evaluation of residual monomer elimination methods in three different fissure sealants in vitro. J Oral Rehabil. 2005;32(2):116-121. doi:10.1111/j.1365-2842.2004.01405.x.

15. Ferracane JL. Elution of leachable components from composites. J Oral Rehabil. 1994;21(4):441-452. doi:10.1111/j.1365-2842.1994.tb01158.x. 
16. Putzeys E, De Nys S, Cokic SM, Duca RC, Vanoirbeek $\mathrm{J}$, Godderis L, et al. Long-term elution of monomers from resin-based dental composites. Dental Materials. 2019;35(3):477-485. doi:10.1016/j.dental.2019.01.005.

17. Hensten-Pettersen A. Skin and mucosal reactions associated with dental materials. Eur J Oral Sci. 1998;106(2 Pt 2):707.

18. Lacerda-Santos R, de Meneses IHC, de Morais Sampaio GA, Pithon MM, Alves PM. Effect of degree of conversion on in vivo biocompatibility of flowable resin used for bioprotection of mini-implants. Angle Orthod. 2016;86(1):157-163. doi:10.2319/112914-856.1.

19. Lee MJ, Kim MJ, Kwon JS, Lee SB, Kim KM. Cytotoxicity of Light-Cured Dental Materials according to Different Sample Preparation Methods. Materials. 2017;10(3):288. doi:10.3390/ma10030288.

20. Zabrovsky A, Beyth N, Pietrokovski Y, Ben-Gal G, HouriHaddad Y. In: Shelton R, editor. 5 - Biocompatibility and functionality of dental restorative materials. Elsevier; 2017. p. 63-75. doi:10.1016/B978-0-08-100884-3.00005-9.

21. Moharamzadeh K, Van Noort R, Brook IM, Scutt AM. HPLC analysis of components released from dental composites with different resin compositions using different extraction media. J Mater Sci Mater Med. 2007;18(1):133-137. doi:10.1007/s10856-006-0671-z.

22. Spencer $\mathrm{P}$, Ye Q, Misra A, Goncalves SdP, Laurence J. Proteins, pathogens, and failure at the compositetooth interface. J Dent Res. 2014;93(12):1243-1249. doi:10.1177/0022034514550039.

23. Mazzoni A, Tjäderhane L, Checchi V, Di Lenarda R, Salo T, Tay FR, et al. Role of Dentin MMPs in Caries Progression and Bond Stability. J Dent Res. 2015;94(2):241-251. doi:10.1177/0022034514562833.

24. Alshali RZ, Salim NA, Sung R, Satterthwaite JD, Silikas N. Analysis of long-term monomer elution from bulk-fill and conventional resin-composites using high performance liquid chromatography. Dent Mater. 2015;31(12):15871598. doi:10.1016/j.dental.2015.10.006.

25. Polydorou O, König A, Hellwig E, Kümmerer K. Long-term release of monomers from modern dental-composite materials. Eur J Oral Sci. 2009;117(1):68-75. doi:10.1111/j.16000722.2008.00594.x.

26. Emmler J, Seiss M, Kreppel H, Reichl FX, Hickel R, Kehe K. Cytotoxicity of the dental composite component TEGDMA and selected metabolic by-products in human pulmonary cells. Dent Mater. 2008;24(12):1670-1675. doi:10.1016/j.dental.2008.04.001.

27. Oysaed H, Ruyter IE, Sjøvik Kleven IJ. Release of formaldehyde from dental composites. J Dent Res. 1988;67(10):1289-1294. doi:10.1177/00220345880670100901.

28. Reichl FX, Durner J, Hickel R, Spahl W, Kehe K, Walther $\mathrm{U}$, et al. Uptake, clearance and metabolism of TEGDMA in guinea pigs. Dent Mater. 2002;18(8):581-589. doi:10.1016/s0109-5641(01)00094-x.

29. Evans SF, Kobrosly RW, Barrett ES, Thurston SW, Calafat AM, Weiss B, et al. Prenatal bisphenol A exposure and maternally reported behavior in boys and girls. Neurotoxicology. 2014;45:91-99. doi:10.1016/j.neuro.2014.10.003.

30. Hong SB, Hong YC, Kim JW, Park EJ, Shin MS, Kim BN, et al. Bisphenol A in relation to behavior and learning of schoolage children. J Child Psychol Psychiatry. 2013;54(8):890899. doi:10.1111/jcpp.12050.

31. Miodovnik A, Engel SM, Zhu C, Ye X, Soorya LV, Silva $\mathrm{MJ}$, et al. Endocrine disruptors and childhood social impairment. Neurotoxicology. 2011;32(2):261-267. doi:10.1016/j.neuro.2010.12.009.

32. Gundert-Remy U, Bodin J, Bosetti C, FitzGerald R, Han- berg A, Hass U, et al. Bisphenol A (BPA) hazard assessment protocol. EFSA Supporting Publications. 2017;14(12):1354E. doi:10.2903/sp.efsa.2017.EN-1354.

33. Assessing and Managing Chemicals under TSCA [Web Page];. Available from: http://www.epa.gov/oppt/ existingchemicals/pubs/actionplans/bpa.html.

34. Kang YG, Kim JY, Kim J, Won PJ, Nam JH. Release of bisphenol A from resin composite used to bond orthodontic lingual retainers. American Journal of Orthodontics and Dentofacial Orthopedics. 2011;140(6):779789. doi:10.1016/j.ajodo.2011.04.022.

35. Fleisch AF, Sheffield PE, Chinn C, Edelstein BL, Landrigan PJ. Bisphenol A and related compounds in dental materials. Pediatrics. 2010;126(4):760-768. doi:10.1542/peds.20092693.

36. Tarumi $H$, Imazato $S$, Narimatsu $M$, Matsuo M, Ebisu S. Estrogenicity of fissure sealants and adhesive resins determined by reporter gene assay. J Dent Res. 2000;79(11):1838-1843. doi:10.1177/00220345000790110401.

37. Berge TLL, Lygre GB, Lie SA, Lindh $\mathrm{CH}$, Björkman L. Bisphenol $\mathrm{A}$ in human saliva and urine before and after treatment with dental polymer-based restorative materials. Eur J Oral Sci. 2019;127(5):435-444. doi:10.1111/eos.12647.

38. Lee JH, Yi SK, Kim SY, Kim JS, Son SA, Jeong SH, et al. Salivary bisphenol A levels and their association with composite resin restoration. Chemosphere. 2017;172:46-51. doi:10.1016/j.chemosphere.2016.12.123.

39. Manoj MK, Ramakrishnan R, Babjee S, Nasim R. Highperformance liquid chromatography analysis of salivary bisphenol A levels from light-cured and chemically cured orthodontic adhesives. Am J Orthod Dentofacial Orthop. 2018;154(6):803-808. doi:10.1016/j.ajodo.2018.02.008.

40. Kingman A, Hyman J, Masten SA, Jayaram B, Smith C, Eichmiller $\mathrm{F}$, et al. Bisphenol A and other compounds in human saliva and urine associated with the placement of composite restorations. J Am Dent Assoc. 2012;143(12):1292-1302. doi:10.14219/jada.archive.2012.0090.

41. Martin M, Bajet D, Woods J, Dills R, Poulten E. Detection of dental composite and sealant resin components in urine. Oral Surg Oral Med Oral Pathol Oral Radiol. 2005;4(99):429. doi:10.1016/j.tripleo.2005.02.014.

42. Marzouk T, Sathyanarayana S, Kim AS, Seminario AL, McKinney CM. A Systematic Review of Exposure to Bisphenol A from Dental Treatment. JDR Clin Trans Res. 2019;4(2):106115. doi:10.1177/2380084418816079.

43. Maserejian NN, Trachtenberg FL, Wheaton OB, Calafat $A M$, Ranganathan G, Kim HY, et al. Changes in urinary bisphenol A concentrations associated with placement of dental composite restorations in children and adolescents. J Am Dent Assoc. 2016;147(8):620-630. doi:10.1016/j.adaj.2016.02.020.

44. Moreira MR, Matos LG, de Souza ID, Brigante TA, Queiroz $\mathrm{ME}$, Romano FL, et al. Bisphenol A release from orthodontic adhesives measured in vitro and in vivo with gas chromatography. Am J Orthod Dentofacial Orthop. 2017;151(3):477-483. doi:10.1016/j.ajodo.2016.07.019.

45. Maserejian NN, Shrader P, Trachtenberg FL, Hauser R, Bellinger DC, Tavares M. Dental sealants and flowable composite restorations and psychosocial, neuropsychological, and physical development in children. Pediatr Dent. 2014;36(1):68-75.

46. Paula AB, Toste D, Marinho A, Amaro I, Marto CM, Coelho $A$, et al. Once resin composites and dental sealants release Bisphenol-A, How might this affect our clinical management? - A systematic review. Int J Environ Res Public Health. 2019;16(9):1627. doi:10.3390/ijerph16091627. 
47. Sasaki N, Okuda K, Kato T, Kakishima H, Okuma H, Abe K, et al. Salivary bisphenol-A levels detected by ELISA after restoration with composite resin. J Mater Sci Mater Med. 2005;16(4):297-300. doi:10.1007/s10856-005-0627-8.

48. Eramo S, Urbani G, Sfasciotti GL, Brugnoletti $O$, Bossù $M$, Polimeni A. Estrogenicity of bisphenol A released from sealants and composites: a review of the literature. Ann Stomatol (Roma). 2010;1(3-4):14-21.

49. Wada H, Tarumi H, Imazato S, Narimatsu M, Ebisu S. In vitro Estrogenicity of Resin Composites. J Dent Res. 2004;83(3):222-226. doi:10.1177/154405910408300307.

50. Manabe A, Kaneko S, Numazawa $S$, Itoh $K$, Inoue $M$, Hisamitsu H, et al. Detection of bisphenol-A in dental materials by gas chromatography-mass spectrometry. Dent Mater J. 2000;19(1):75-86. doi:10.4012/dmj.19.75.

51. Schmalz G, Preiss A, Arenholt-Bindslev D. BisphenolA content of resin monomers and related degradation products. Clin Oral Investig. 1999;3(3):114-119. doi:10.1007/s007840050088.

52. Al-Hiyasat AS, Darmani H, Milhem MM. Cytotoxicity evaluation of dental resin composites and their flowable derivatives. Clin Oral Investig. 2005;9(1):21-25. doi:10.1007/s00784-004-0293-0.

53. Gupta SK, Saxena P, Pant VA, Pant AB. Release and toxicity of dental resin composite. Toxicol Int. 2012;19(3):225. doi:10.4103/0971-6580.103652.

54. Marquardt W, Seiss M, Hickel R, Reichl FX. Volatile methacrylates in dental practices. J Adhes Dent. 2009;11(2):101-107. doi:10.3290/j.jad.a15321.

55. Van Landuyt KL, Nawrot $T$, Geebelen B, De Munck J, Snauwaert J, Yoshihara $\mathrm{K}$, et al. How much do resin-based dental materials release? A metaanalytical approach. Dent Mater. 2011;27(8):723-747. doi:10.1016/j.dental.2011.05.001.

56. Al-Hiyasat AS, Darmani H. In vivo effects of BISGMA-a component of dental composite-on male mouse reproduction and fertility. J Biomed Mater Res A. 2006;78A(1):6672. doi:https://doi.org/10.1002/jbm.a.30667.

57. Seiss M, Marquardt W, Hickel R, Reichl FX. Excretion of dental resin monomers and metabolic intermediates via urine in guinea pigs. Dent Mater. 2009;25(4):481-485. doi:10.1016/j.dental.2008.08.013.

58. Guidance on the Application of the CLP Criteria [Web Page];. Available from: https://echa. europa.eu/documents/10162/23047722/clp_criteria_hh_ revised_draft_guidance_rev_7_rac_forum_201305_en.pdf/ fddb2d48-4007-47b3-9816-50d2b8ea33d0.

59. Gonçalves F, Campos LMdP, Rodrigues-Júnior EC, Costa FV, Marques PA, Francci CE, et al. A comparative study of bulk-fill composites: degree of conversion, postgel shrinkage and cytotoxicity. Braz Oral Res. 2018;32. doi:10.1590/1807-3107bor-2018.vol32.0017.

60. Nascimento AS, Lima DB, Fook MVL, Albuquerque MSd, Sabino MA, Borges SMP, et al. Physicomechanical characterization and biological evaluation of bulk-fill composite resin. Braz Oral Res. 2018;32. doi:10.1590/1807-3107bor2018.vol32.0107.

61. Susila AV, Balasubramanian V. Correlation of elution and sensitivity of cell lines to dental composites. Dental Materials. 2016;32(3):e63-e72. doi:10.1016/j.dental.2015.11.011.

62. Geurtsen W, Lehmann F, Spahl W, Leyhausen G. Cytotoxicity of 35 dental resin composite monomers/additives in permanent $3 \mathrm{~T} 3$ and three human primary fibroblast cultures. J Biomed Mater Res A. 1998;41(3):474-480. doi:10.1002/(sici)1097-4636(19980905)41:3<474::aidjbm18>3.0.co;2-i.

63. Brzović Rajić V, Želježić D, Malčić Ivanišević A, Verzak Z, Baraba A, Miletić I. Cytotoxicity and Genotoxic- ity of Resin Based Dental Materials in Human Lymphocytes In Vitro. Acta Clin Croat. 2018;57(2):278-285. doi:10.20471/acc.2018.57.02.07.

64. Birben E, Sahiner UM, Sackesen C, Erzurum S, Kalayci O. Oxidative stress and antioxidant defense. World Allergy Organ J. 2012;5(1):9-19. doi:10.1097/WOX.ob013e3182439613.

65. Kurutas EB. The importance of antioxidants which play the role in cellular response against oxidative/nitrosative stress: current state. Nutr J. 2016;15(1):71. doi:10.1186/s12937-016-0186-5.

66. Engelmann J, Janke V, Volk J, Leyhausen G, Von Neuhoff $\mathrm{N}$, Schlegelberger B, et al. Effects of BisGMA on glutathione metabolism and apoptosis in human gingival fibroblasts in vitro. Biomaterials. 2004;25(19):4573-4580. doi:10.1016/j.biomaterials.2003.11.048.

67. Volk J, Engelmann J, Leyhausen G, Geurtsen W. Effects of three resin monomers on the cellular glutathione concentration of cultured human gingival fibroblasts. Dent Mater. 2006;22(6):499-505. doi:10.1016/j.dental.2005.06.002.

68. Chang HH, Guo MK, Kasten $\mathrm{FH}$, Chang $\mathrm{MC}$, Huang GF, Wang YL, et al. Stimulation of glutathione depletion, ROS production and cell cycle arrest of dental pulp cells and gingival epithelial cells by HEMA. Biomaterials. 2005;26(7):745-753. doi:10.1016/j.biomaterials.2004.03.021.

69. Chang MC, Chen LI, Chan CP, Lee JJ, Wang TM, Yang TT, et al. The role of reactive oxygen species and hemeoxygenase-1 expression in the cytotoxicity, cell cycle alteration and apoptosis of dental pulp cells induced by BisGMA. Biomaterials. 2010;31(32):8164-8171. doi:10.1016/j.biomaterials.2010.07.049.

70. Stanislawski L, Lefeuvre M, Bourd K, Soheili-Majd E, Goldberg $M$, Périanin A. TEGDMA-induced toxicity in human fibroblasts is associated with early and drastic glutathione depletion with subsequent production of oxygen reactive species. J Biomed Mater Res A. 2003;66(3):476482. doi:10.1002/jbm.a.10600.

71. Chang HH, Chang MC, Wang HH, Huang GF, Lee YL, Wang YL, et al. Urethane dimethacrylate induces cytotoxicity and regulates cyclooxygenase-2, hemeoxygenase and carboxylesterase expression in human dental pulp cells. Acta Biomater. 2014;10(2):722-731. doi:10.1016/j.actbio.2013.10.006.

72. Nocca G, De Palma F, Minucci A, De Sole P, Martorana GE, Callà $\mathrm{C}$, et al. Alterations of energy metabolism and glutathione levels of HL-60 cells induced by methacrylates present in composite resins. J Dent. 2007;35(3):187-194. Available from: http://www.sciencedirect.com/science/article/pii/ S0300571206001503. doi:10.1016/j.jdent.2006.07.008.

73. Schweikl H, Hartmann A, Hiller KA, Spagnuolo G, Bolay $\mathrm{C}$, Brockhoff $\mathrm{G}$, et al. Inhibition of TEGDMA and HEMA-induced genotoxicity and cell cycle arrest by N-acetylcysteine. Dent Mater. 2007;23(6):688-695. doi:10.1016/j.dental.2006.06.021.

74. Schweikl H, Spagnuolo G, Schmalz G. Genetic and cellular toxicology of dental resin monomers. J Dent Res. 2006;85(10):870-877. doi:10.1177/154405910608501001.

75. Reichl FX, Esters M, Simon S, Seiss M, Kehe K, Kleinsasser $\mathrm{N}$, et al. Cell death effects of resin-based dental material compounds and mercurials in human gingival fibroblasts. Arch Toxicol. 2006;80(6):370-377. doi:10.1007/s00204005-0044-2.

76. Ahmed RH, Aref MI, Hassan RM, Mohammed NR. Cytotoxic effect of composite resin and amalgam filling materials on human labial and buccal epithelium. Nature and science. 2010;8(10):48-53.

77. Issa Y, Watts D, Brunton P, Waters C, Duxbury A. Resin 
composite monomers alter MTT and LDH activity of human gingival fibroblasts in vitro. Dent Mater. 2004;20(1):12-20. doi:10.1016/S0109-5641(03)00053-8.

78. Johnson MD, Schilz J, Djordjevic MV, Rice JR, Shields PG. Evaluation of in vitro assays for assessing the toxicity of cigarette smoke and smokeless tobacco. Cancer Epidemiol Biomarkers Prev. 2009;18(12):3263-3304. doi:10.1158/1055-9965.EPI-09-0965.

79. Huang FM, Kuan YH, Lee SS, Chang YC. Cytotoxicity and genotoxicity of triethyleneglycol-dimethacrylate in macrophages involved in DNA damage and caspases activation. Environ Toxicol. 2015;30(5):581-588. doi:10.1002/tox.21935.

80. Shehata M, Durner J, Eldenez A, Van Landuyt K, Styllou $\mathrm{P}$, Rothmund $\mathrm{L}$, et al. Cytotoxicity and induction of DNA double-strand breaks by components leached from dental composites in primary human gingival fibroblasts. Dent Mater. 2013;29(9):971-979. doi:10.1016/j.dental.2013.07.007.

81. Wisniewska-Jarosinska M, Poplawski T, Chojnacki CJ, Pawlowska E, Krupa R, Szczepanska J, et al. Independent and combined cytotoxicity and genotoxicity of triethylene glycol dimethacrylate and urethane dimethacrylate. Mol Biol Rep. 2011;38(7):4603-4611. doi:10.1007/s11033-0100593-1.

82. Li Y, Kuan Y, Huang F, Chang Y. The role of DNA damage and caspase activation in cytotoxicity and genotoxicity of macrophages induced by bisphenol-Aglycidyldimethacrylate. Int Endod J. 2012;45(6):499-507. doi:10.1111/j.1365-2591.2011.02001.x.

83. Di Pietro A, Visalli G, La Maestra S, Micale R, Baluce B,
Matarese G, et al. Biomonitoring of DNA damage in peripheral blood lymphocytes of subjects with dental restorative fillings. Mutat Res/Genet Toxicol Environ Mutagen. 2008;650(2):115-122. doi:10.1016/j.mrgentox.2007.10.023.

84. Pettini F, Savino M, Corsalini M, Cantore S, Ballini A. Cytogenetic genotoxic investigation in peripheral blood lymphocytes of subjects with dental composite restorative filling materials. J Biol Regul Homeost. 2015;29(1):229-233.

85. Tadin A, Marovic D, Galic N, Milevoj A, Medvedec Mikic I, Zeljezic D. Genotoxic biomonitoring of flowable and non-flowable composite resins in peripheral blood leukocytes. Acta Odontol Scand. 2013;71(3-4):923-929. doi:10.3109/00016357.2012.734419.

86. Hansel C, Leyhausen G, Mai UE, Geurtsen W. Effects of various resin composite (co)monomers and extracts on two caries-associated micro-organisms in vitro. J Dent Res. 1998;77(1):60-67. doi:10.1177/00220345980770010601.

87. Khalichi P, Cvitkovitch DG, Santerre JP. Effect of composite resin biodegradation products on oral streptococcal growth. Biomaterials. 2004;25(24):5467-5472. doi:10.1016/j.biomaterials.2003.12.056.

88. Bergenholtz G. Evidence for bacterial causation of adverse pulpal responses in resin-based dental restorations. Crit Rev Oral Biol Med. 2000;11(4):467-480. doi:10.1177/10454411000110040501.

89. Di Giulio M, D'Ercole S, Zara S, Cellini L. Streptococcus mitis/human gingival fibroblasts co-culture: The best natural association in answer to the 2-hydroxyethyl methacrylate release. APMIS. 2012;120:139-146. doi:10.1111/j.16000463.2011.02828.x. 